\title{
ПРОБЛЕМИ ПРАВОВОГО РЕГУЛЮВАННЯ ДОГОВОРУ ЕКОЛОГІЧНОГО КРАУДФАНДИНГУ
}

Шуміло О. М.

У науковій статmі досліджені науково-прикладну проблему вдосконалення понятійно-категоріального апарату договору екологічного краудфандингу. Проаналізовано доктринальні підходи до питання, якими необхідно вважати відносини щодо екокраудфандингу: публічними чи приватноправовими. Автор обгрунтовує необхідність закріплення в законодавстві дефініції терміна «договір краудфандингу». Розкрито правову природу договору екологічного краудфандингу. Досліджено форму договору, зроблено висновок про унікальну правову природу, яка не дозволяє повністю регулювати такі відносини чинними національними нормами права. 3 урахуванням зарубіжного досвіду правового регулювання екологічного краудфандингу зроблено висновки щодо необхідності вдосконалення правового регулювання цього інституту в Україні.

Ключові слова: екологічний краудфандинг, колективне фінансування, екологічні проєкти, договір екокраудфандингу, правова природа екокраудфандингу.

В научной статье исследована научно-прикладная проблема совершенствования понятийно-категориального aпnарата договора экологического краудфандинга. Проанализированы доктринальные подходы к данному вопросу, какими всё же следует считать отношения по эко-краудфандингу: публичными или частно-правовыми. Автор обосновывает необходимость закрепления в законодательстве дефиниции термина «договор краудфандинга». Раскрыто правовую природу договора экологического краудфандинга. Исследована форма договора, сделан вывод об уникальной правовой природе, которая не позволяет полно регулировать отношения данного типа существующими национальными нормами права. С учетом зарубежного опыта правового регулирования экологического краудфандинга сделаны выводы о необходимости совершенствования правового регулирования этого института в Украине.

Ключевые слова: экологический краудфандинг, коллективное финансирование, экологические проекты, договор экокраудфандинга, правовая природа экокраудфандинга.

Shumilo 0. M. The problems of environmental crowdfunding agreement legal regulation

The research article is dedicated to solving the theoretical and practical problems of improving the conceptual and categorical apparatus of environmental crowdfunding agreement. Such projects do not provide financial rewards for social investors, but only morally (non-financial) encourage their supporters. Depending on the funding model of crowdfunding donations, it usually appears in the form of irrevocable inappropriate financial assistance.

An important place among the crowdfunding-funded projects belongs to the ones on: sustainable development (climate), green energy, green (environmental) tourism and environmental education.

It was noted that the impetus for crowdfunding the environmental projects was the tax restrictions on the possibility

(с) Шуміло О. М., 2020 of transferring funds instead of contributions to the budget for environmental (social) projects

The article analyzes the doctrinal approaches to what should be considered relations on eco-crowdfunding: public or private law. The author insists on the need to take into account the constitutional principles, i.e. the obligation not to harm nature, cultural heritage, to compensate for the caused losses. Thus, environmental protection is recognized as everyone's responsibility, and everyone has the right to a favorable environment. Thus, there is a need for public law means of ensuring constitutional environmental requirements. On the other hand, the presence of certain natural objects in private, state, municipal and other forms of ownership, the free right to use natural objects of the national property right in accordance with the law (if it is not used to the detriment of man and society and does not harm the environment and does not worsen environmental situation and natural properties of the land), includes private law methods in the regulation of public environmental relations.

The author substantiates the need to consolidate the definition of the "crowdfunding agreement" in the legislation. The legal essence of environmental crowdfunding agreement is disclosed. The form of the contract is investigated, the conclusion is made about the unique legal nature, which does not allow to fully regulate relations of this type in the existing national legal framework. Based on foreign experience in the legal regulation of environmental crowdfunding, conclusions are drawn about the need to improve the legal regulation of this institute in Ukraine.

Key words: environmental crowdfunding, co-financing, environmental projects, eco-crowdfunding agreement, legal essence of eco-crowdfunding.

Постановка проблеми та іï актуальність. За останнє десятиліття інститут екологічного краудфандингу набув небувалого розвитку. Адже незалежне фінансування нагальних екологічних проєктів $\epsilon$ невіддільною частиною сучасного суспільства. 3 огляду на це все більшого значення набуває створення ефективної та дієвої системи правового регулювання екологічного краудфандингу.

Ключовим правовим інструментом охорони прав учасників екологічних краудфандингових правовідносин виступає нормативно-правове регулювання такого договору. Він $\epsilon$ правовим засобом досягнення основної мети екологічного краудфандингу - своєчасне фінансове забезпечення ініціативної групи для реалізації нагального екологічного проєкту.

Суттєвими перепонами на шляху створення дієвих правових засобів захисту прав учасників екологічних краудфандингових правовідносин $€$ відсутність ефективного правового регулювання такої діяльності, недостатня розробленість на законодавчому рівні понятійно-категоріального апарату договору екологічного краудфандингу, що й зумовлює необхідність детальнішого аналізу обраної проблематики. 


\section{Проблеми \\ екологічного законодавства}

Аналіз останніх досліджень і публікацій. На доктринальному рівні договірні відносини у сфері екологічного краудфандингу були предметом наукових розвідок таких учених, як Д.В. Попович, Н.В. Назар, Н.В. Савчин, О.З. Уголькова, О.М. Шевченко, О.О. Казак, І.П. Васильчук. Проте низка питань, пов'язаних із визначенням місця цього новітнього інституту, його основних категорій, розкриттям його еколого-правової природи, залишилися поза увагою наукової спільноти або все ще $\epsilon$ дискусійною.

Метою статті $\epsilon$ дослідження особливостей правової природи екологічного краудфандингу як новітнього міжгалузевого правового інституту, що дозволяє громадськості отримати фінансову підтримку для поліпшення стану довкілля від донорів, яка $\epsilon$ передумовою формування сталого розвитку країни.

Виклад основного матеріалу. Головною умовою й поштовхом переходу до збору коштів для екологічних проєктів шляхом краудфандингу (колективного фінансування) стане подальший розвиток громадянського суспільства в нашій країні. Залежно від різних типів проєктів та технологій збору фінансових коштів краудфандинг щодо екологічних проєктів, враховуючи його мету, прийнято відносити до соціальних, які викликані браком коштів. Такі проєкти й надалі залишаються одними із ключових. Вони не передбачають фінансової винагороди для соціальних інвесторів, а лише морально (нефінансово) заохочують своїх прихильників. Залежно від моделі фінансування проєктів краудфандинг-пожертвування, як правило, виступає у вигляді безповоротної нецільової фінансової допомоги [1].

Важливе місце серед екологічних проєктів, що фінансуються за допомогою краудфандингу, є проєкти щодо сталого розвитку та зеленої енергетики. Багато неприбуткових організацій звернулись до краудфандингових платформ, оскільки індивідуальні внески чи банківські позики важче отримати. Кредитні та грантові програми, які діють в Україні, пов'язані з проєктами енергоефективності від міжнародних фінансових установ, зокрема ЄБРР, Світового та Європейського інвестиційного банків, що орієнтовані на сектор малого та середнього бізнесу.

Окремий напрямок краудфандингу - екокраудфандинг - широко застосовується у світовій практиці. Наприклад, у 2009 році вийшла у світ кінострічка документалістів «Століття дурнів», котра розкриває проблеми кліматичних змін на планеті. На виробництво цієї стрічки збирали кошти майже п'ять років і внаслідок цього було отримано бюджет понад 900 тисяч фунтів стерлінгів, які надали близько 600 прихильників. У Великій Британії громадська організація «10:10» розпочала кліматичний проєкт “Solar School”, який забезпечує деякі англійські школи сонячними панелями [2].

Окрім кліматичних та енергетичних проєктів, на українських краудфандингових платформах реалізовано декілька проєктів, присвячених зеленому (екологічному) туризму [3].

Новітньою в Україні $\epsilon$ ідея, започаткована міжнародною благодійною організацією «Екологія-Право-Людина» за допомогою краудфандингової інтернет-платформи Львівська Каса в межах екологічної програми підтримки проведення просвітницьких екологічних тренінгів. Вони присвячені процедурі прийняття та погодження із громадою Стратегічної екологічної оцінки та Оцінки впливу на довкілля.
Можливість реалізації екологічних проєктів та їх особливості через краудфандингові платформи в Україні констатуються в багатьох наукових працях.

Так, Д.В. Попович, Н.В. Назар, Н В. Савчин у науковій статті зазначають, що в Україні мають бувають екологічні проєкти. Але водночас акцентують, що українські проєкти носять переважно соціальний характер, тоді як за кордоном більше цінуються технологічні новинки [4].

У своєму дисертаційному дослідженні 0.3. Уголькова зазначає, що проблема недостатньої забезпеченості фінансовими ресурсами продовжує бути одним із найважливіших викликів для організацій, які займаються екологічними проєктами, що $є$ ключовими на краудфандингових платформах [5].

Аналізуючи розвиток краудфандингу в умовах цифрової трансформації економіки України, О.М. Шевченко та О.О. Казак підтримують тезу щодо екологічних проєктів, які відносяться до краудфандингу без винагороди інвестору, а пожертви зазвичай $є$ добровільними актами, зробленими на основі альтруїзму й без будьяких зобов'язань для одержувача. Але, на їх думку, альтруїзм інвесторів має свої межі, що стримує можливості соціального краудфандингу і звужує коло проєктів, які можуть бути профінансовані таким чином [6].

Наостанок І.П. Васильчук стверджує, що концепція стійкого розвитку, яка ґрунтується на ідеології соціальної відповідальності соціуму й бізнесу, завдяки краудфандингу отримала ще одне джерело фінансування соціальних та екологічних проєктів - кошти широкого загалу (домогосподарств) [7].

Однією з основних причин бурхливого зростання краудфандингового фінансування екологічних проєктів в Україні $\epsilon$ податкове обмеження щодо можливості передавати кошти замість внесків до бюджету на соціальні проєкти.

Проаналізувавши економічну та юридичну літературу, а також краудфандингові платформи, можна дійти висновку щодо основних складників етапів їх функціонування, а саме: краудфандингова платформа створюється з метою допомоги зібрати кошти (фінансування) екологічного проєкту для досягнення позитивного соціального (некомерційного) ефекту, де джерелом коштів виступають унески третіх осіб (благодійників).

Юридичне оформлення платформи для запуску збору коштів шляхом краудфандингу може складатись із таких етапів [8]:

оформлення правил краудфандингової платформи, що $є$ публічною пропозицією;

укладення договору між краудплатформою та автором проєкту [9] (договір про наміри на початку збору коштів та укладення договору про надання гранту після збору суми, а в разі збору для фізичної особи - підприємця ФОП - укладення договору про спільну діяльність);

укладення договору між краудплатформою та користувачем;

додатково може укладатись договір здійснення приймання платежів;

укладення договору про конфіденційність [10], а в разі спрямованості на європейський ринок Загального регламенту щодо захисту даних Європейського Союзу (General Data Protection Regulation, GDPR Compliance) [11; 12]. 
Одержувачем (бенефіціаром) зібраних коштів може бути сама особа як ініціатор проєкту або визначений раніше підрядник (спеціалізована організація або постачальник). За наявності підрядника ініціатор збору коштів - благо отримувач - укладає договір із підрядником (спеціалізованою організацією або постачальником). Саме ця особа буде одержувачем (бенефіціаром) коштів, зібраних від благодійників (третіх осіб), котрі перерахують кошти на краудфандингову платформу.

Відповідальність щодо залучення коштів покладається на ініціатора збору благодійних пожертв для екологічних проєктів. Тобто оголошується публічна оферта та оприлюднюється публічний договір. Згідно з положеннями ст.ст. 633, 641 ЦК України [13] умови публічної оферти та публічного договору встановлюються однаковими для всіх споживачів. Отримувачем фінансової допомоги може бути: приватна особа, ініціативна група, громадська організація зі статусом юридичної особи або без такого статусу чи благодійний фонд. Це дозволяє небайдужим громадянам оперативно отримати кошти для охорони довкілля, на відміну від міжнародних фондів-грантодавців, які вимагають обов'язкової реєстрації тощо.

Цивільно-правовими відносинами також врегульовують питання щодо захисту авторських прав проєкту, виставленого на краудфандинговій платформі. Адже й сам веб-сайт і веб-сторінка $є$ об'єктами авторського та суміжних прав згідно із Законом України «Про авторське право й суміжні права» [14].

Закономірно постає питання, якими варто вважати відносини щодо екокраудфандингу: публічними чи приватноправовими. Оцінюючи це, потрібно зауважити, що, згідно зі ст. 66 Конституції України [15], кожен зобов'язаний не заподіювати шкоду природі, культурній спадщині, відшкодовувати завдані ним збитки. Тобто охорона навколишнього природного середовища визнається обов'язком кожного, і право на сприятливе довкілля теж має кожний. Таким чином, постає потреба в публічно-правових засобах забезпечення екологічних конституційних приписів. 3 іншого боку, перебування деяких природних об'єктів у приватній, державній, муніципальній та інших формах власності, вільне право користування природними об'єктами права власності народу, відповідно до закону (якщо це не використовується на шкоду людині й суспільству та не завдає шкоди довкіллю й не погіршує екологічну ситуацію і природні якості землі), на що вказують ст. ст. 13, 41 Конституції України [15], включає в регулювання суспільних екологічних відносин приватноправові методи.

Однак необхідно розрізняти краудфандинг звичайний та екологічний, тобто той, який має на меті збір коштів, що будуть спрямовані для поліпшення стану довкілля. Вчені, як правило, застосовують комплексний підхід для розмежування публічно-правових відносин від приватноправових і вважають, що у краудфандингових правовідносинах відбувається переважно диспозитивне (субсидіарне) правове регулювання. Сторони вільні у встановленні відносин, неврегульованих нормами цивільного права, але водночас не суперечать його основним засадам, правилам взаємодії. Однак варто зазначити, що краудфандингові правовідносини не можуть повністю обійтись без використання імперативних правил, зокрема заборон (ліцензування, встановлення максимальних обмежень щодо збору та пожертви, заборони використання біткоїнів, цільового використання природних об'єктів). Тобто здійснюється регуляторний вплив державних установ на процес екологічного краудфандингу.

Щодо суб'єктів краудфандингових правовідносин, то вони знаходяться між собою у відносинах координації, а не субординації, тобто учасники юридично рівні між собою. Тому цивілісти переважно краудфандинг відносять до галузі приватного права [16]. Однак одним з основних питань стабільного функціонування неурядових громадських організацій $\epsilon$ їх фінансування. I тому, згідно із законодавством, цільове фінансування може здійснюватись державними та муніципальними органами, що дещо ширше цивільних правовідносин. Можуть також долучатись до фінансування громадських організацій корпоративний сектор або фізичні особи - доброчинці - за допомогою екологічного краудфандингу.

У юридичних колах ще не сформувалась юридична позиція щодо того, до якого виду договорів необхідно відносити краудфандинг. Уважають, що краудфандинг може мати риси договорів: дарування, простого товариства, а також купівлі-продажу (з попередньою оплатою) $[17 ; 18]$. Але розв'язати цю дискусію зможе спеціальний закон або зміни до відповідних нормативних актів. Поки що порівняння краудфандингу з одним із чинних на сьогодні договірних інститутів видається некоректним [19], і вважаємо, що із цим варто погодитись як із правовою новелою.

Отже, законодавством не визначено спеціальні умови для краудфандингу, але його застосування можливе в межах загального договірного права [20].

Висновки. Термін «краудфандинг» законодавець використовує, однак відносини, які охоплюються цим терміном, в Україні цієї миті законодавчо не врегульовані. Хоча широко застосовується процедура публічного збору благодійних пожертв шляхом краудфандингу. За своєю правовою природою краудфандинг, й екологічний зокрема, найбільше схожий із наданням послуг, пожертвуванням і даруванням. Проте це не означає, що відносини у сфері краудфандингу повинні регулюватись нормами, які застосовуються до вказаних правових інститутів. Варто погодитись із пропозицією, що, якщо краудфандинг, який має безоплатну основу, може бути визнаний різновидом інституту дарування, а фінансування, котре має оплатну основу, має унікальну правову природу, яка не дозволяє регулювати такі відносини вже діючими нормами права, то у зв'язку із цим для регулювання відносин, що складаються у сфері краудфандингу, варто, напевно, виділити окрему главу у цК України чи прийняти спеціальний закон із внесенням змін у відповідні законодавчі акти.

\section{Література}

1. Красномовець В.А., Рой А.І. Сучасний стан та перспективи розвитку краудфандингу в Україні. Сучасні підходи до управління підприємством: зб. наук. пр. 2016. № 1. Режим доступу: http://spu.fmm.kpi.ua/article/ view/72884 (дата звернення: 21.01.2020).

2. Шевченко Анастасія. Краудфандінг - нове джерело екофінансування. Сайт Кліматlнфо. Режим доступу: http://www.climateinfo.org.ua/content/kraudfanding-novedzherelo-eko-finansuvannya (дата звернення: 21.01.2020).

3. Будуємо кемпінг в актовському каньйоні. Режим доступу: https://biggggidea.com/project/aktovo/ (дата звернення: 21.01.2020). 
4. Попович Д.В., Назар Н.В., Савчин Н.В. Краудфандинг як новітній спосіб фінансування в Україні. Молодий вчений. 2018. № 10(2). С. 873-876 Режим доступу: http: / / molodyvcheny.in.ua/files/journal/2018/10/200.pdf (дата звернення: 21.01.2020).

5. Уголькова 0.3. Оцінювання та державне регулювання систем краудфандингу в національній економіці : дис. ... канд. екон. Наук : 08.00 .03 - економіка та управління національним господарством; Міністерство освіти науки України; Національний університет «Львівська політехніка». Львів, 2019. 227 с. [Електронний ресурс]. Режим доступу: http://ena.lp.edu.ua/bitstream/ntb/44827/3/ dyser_ugolkova.pdf (дата звернення: 21.01.2020).

6. Шевченко О.М., Казак О.О. Розвиток краудфандингу в умовах цифрової трансформації економіки України. Ефективна економіка. 2019. № 3. Режим доступу: http://www.economy.nayka.com.ua/?op=1\&z=6957 (дата звернення: 21.01.2020).

7. Васильчук І.П. Краудфандінг як феномен постіндустріальної економіки. Ефективна економіка: електр. наук. фах. вид.; Дніпропетр. держ. агр.-екон. ун-т. Електрон. текст. дані. Дніпропетровськ, 2013. № 11. Режим доступу: http:/ / www.economy.nayka.com.ua/ ?op=1\&z=2500\&p=1 (дата звернення: 21.01.2020).

8. Цвик О. Регулювання краудфандингу в Україні та США [Електронний ресурс]. Режим доступу: https:// blog.liga.net/user/atsvyk/article/32690 (дата звернення: 21.01.2020).

9. Правила Спільнокошту. Сайт краудфандингової платформи «Велика Ідея». Режим доступу: https://biggggidea.com/pages/spilnokosht/ (дата звернення: 21.01.2020).

10. Угода про конфіденційність. Сайт краудфандингової платформи «Велика Ідея». Режим доступу: https://biggggidea.com/pages/confidential/ (дата звернення: 21.01.2020).

11. Directive 95/46/EC of the European Parliament and of the Council of 24 October 1995 on the protection of individuals with regard to the processing of personal data and on the free movement of such data, eur-lex.europa.eu. [Electronic resource]. Access mode https://eur-lex.europa.eu/legalcontent/EN/LSU/?uri=celex\%3A31995L0046 (last accessed: 21.01.2020). Heading from the screen.

12. Causes Privacy Policy. Causes. [Electronic resource]. Access mode https://www.causes.com/privacy (last accessed: 21.01.2020). Heading from the screen.

13. Цивільний кодекс України від 16.01.2003 р. за № 435-IV. Офіційний вісник України. 2003. № 11 (28.03.2003). Ст. 461.

14. Про авторське право і суміжні права: Закон України від 23.12.1993 р. за № 3792-ХІІ. Відомості Верховної Ради України. 1994. № 13(29.03.94). Ст. 64.

15. Конституція України: Закон України від 28.06.1996 р. за № 254к/96-ВР. Відомості Верховної Ради України. 1996. № 30 (23.07.96). Ст. 141.

16. Саяпин С.П. К вопросу о правовой природе краудфандинга. Вопросы российского и международного права. 2019. Том 9. № 5A. С. 170-176.

17. Алексеев Н.В. Краудфандинг: от реализации частной инициативы к решению общественных проблем. Бюллетень науки и практики. 2016. № 10(11). С. 271-277.

18. Архипов Е.И. Понятие и правовая природа краудфандинга. Актуальные проблемы предпринимательского права. Москва : Стартап, 2015. Вып. 4. С. 18-27.

19. Клинов А.О. Правовое регулирование краудфандинга в России и за рубежом. Закон. 2018. № 2. С. 90-105.

20. Про схвалення Стратегії розвитку малого i середнього підприємництва в Україні на період до 2020 року: Розпорядження Кабінету Міністрів України від 24.05.2017 р. за № 504-р. Офіційний вісник України. 2017. № 63(11.08.2017). Ст. 1913.

Шуміло О. М., кандидат юридичних наук, доцент кафедри правового забезпечення господарської діяльності факультету № 6 Харківського національного університету внутрішніх справ 